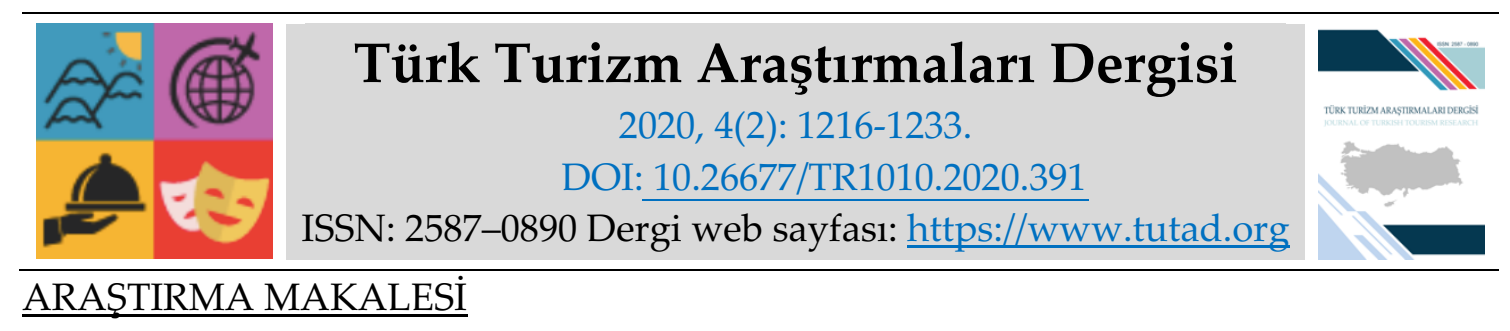

\title{
Konaklama İşletmelerinde Lider-Üye Etkileşiminin Örgütsel Bağlılık ve İş Tatmini Üzerindeki Etkisine Yönelik Bir Araştırma*
}

Cüneyt TAT, Doktora Öğrencisi, Alanya Alaaddin Keykubat Üniversitesi, Lisansüstü Eğitim Enstitüsü, Alanya, e-posta: cuneyttat07@gmail.com

ORCID: https://orcid.org/0000-0003-4218-6918

Dr. Öğr. Üyesi Aydın ÇEVİRGEN, Alanya Alaaddin Keykubat Üniversitesi, Turizm Fakültesi, Alanya, e-posta: aydin.cevirgen@alanya.edu.tr

ORCID: https://orcid.org/0000-0002-3245-8783

Öz

Bu çalışmada Lider-Üye Etkileşimi (LÜE) etki, bağlılık, katkı ve profesyonel saygıyı içeren çok boyutlu bir yaklaşımla ele alınarak, LÜE kalitesinin çalışanların örgütsel bağlllık ve iş tatminleri üzerindeki etkisinin belirlenmesi amaçlanmıştır. Çalışmanın evreni olarak Antalya Belek bölgesindeki beş yıldızlı konaklama işletmelerindeki çalışanlar seçilmiştir. Araştırma için gerekli olan veriler anket formu ile elde edilmiştir. Alan araştırmasında kolayda örnekleme yöntemi kullanılarak elde edilen veriler istatistik paket yazılımı ile değerlendirmeye alınmıştır. İstatistiksel analizde pearson korelasyon ve çoklu regresyon analizi kullanılmıştır. Araştırma sonucunda lider-üye etkileşimin profesyonel saygı alt boyutunun duygusal bağlllık ve normatif bağlllık üzerinde anlamlı ve pozitif bir etkisinin olduğu belirlenmiştir. Diğer sonuçlar ise bağlılık ve profesyonel saygı alt boyutlarının iş tatmini üzerinde anlamlı ve pozitif bir etkisinin olduğunu göstermektedir.

*Bu makale Cüneyt TAT'ın yüksek lisans tezinden üretilmiştir.

Anahtar Kelimeler: Lider-Üye Etkileşimi, Örgütsel Bağlılık, İş Tatmini, Konaklama İşletmeleri, Antalya.

Makale Gönderme Tarihi: 17.12.2019

Makale Kabul Tarihi: 04.04.2020

\section{Önerilen Atıf:}

Tat, C. ve Çevirgen, A. (2020). Konaklama İşletmelerinde Lider-Üye Etkileşiminin Örgütsel Bağllık ve İş Tatmini Üzerindeki Etkisine Yönelik Bir Araştırma, Türk Turizm Araştırmaları Dergisi, 4(2): 1216-1233.

(C) 2020 Türk Turizm Araştırmaları Dergisi. 


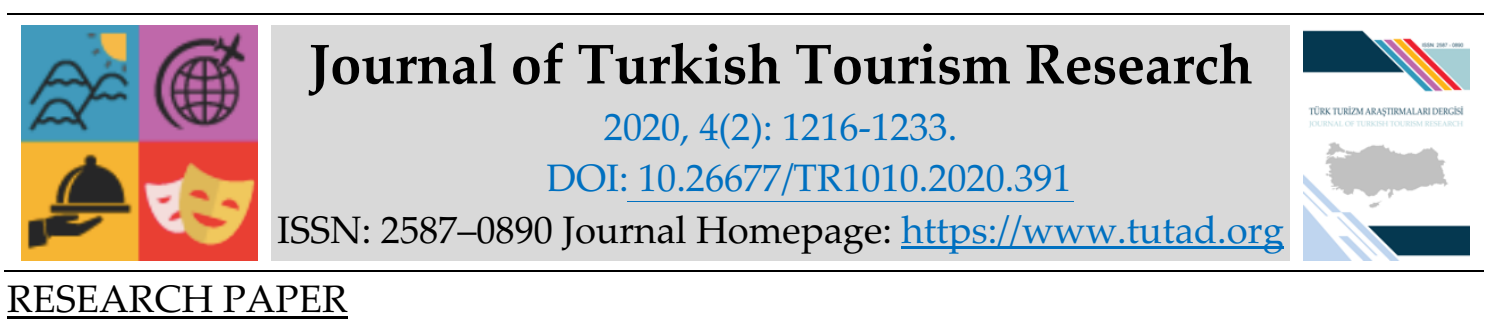

\title{
A Research on The Effect of Leader-Member Exchange on Organizational Commitment and Job Satisfaction in Accommodation Establishments
}

Cüneyt TAT, Ph.D. Student, Alanya Alaaddin Keykubat University, Institute of Graduate Programs, Alanya, e-mail: cuneyttat07@gmail.com

ORCID: https://orcid.org/0000-0003-4218-6918

Assistant Prof. Dr. Aydın ÇEVIRGEN, Alanya Alaaddin Keykubat University, Faculty of Tourism, Alanya, e-mail: aydin.cevirgen@alanya.edu.tr

ORCID: https://orcid.org/0000-0002-3245-8783

\begin{abstract}
In this study, it was aimed to determine the effect of Leader-Member Exchange (LMX) quality on organizational commitment and job satisfaction of the employees by taking a multidimensional approach including effect, commitment, contribution and professional respect. As the population of the study, employees in the five stars hotels in Antalya Belek region were selected. The data required for the research were obtained by a questionnaire. The data gathered by using convenience sampling in the field research was evaluated with statistical package software. Pearson correlation and multiple regression were used in the statistical analysis. As a result of the research, it was determined that the professional respect, which is one of the sub-dimensions of leader-member exchange, has a significant positive effect on emotional and normative commitment. The other results indicate that sub-dimensions of leader-member exchange, which are loyalty and professional respect have a positive effect on job satisfaction.
\end{abstract}

Keywords: Leader-Member Exchange, Organizational Commitment, Job Satisfaction, Accommodation Establishment, Antalya.

Received: 17.12 .2019

Accepted: 04.04.2020

\section{Suggested Citation:}

Tat, C. and Çevirgen, A. (2020). A Research on The Effect of Leader-Member Exchange on Organizational Commitment and Job Satisfaction in Accommodation Establishments, Journal of Turkish Tourism Research, 4(2): 1216-1233.

(C) 2020 Türk Turizm Araştırmaları Dergisi. 


\section{Gíriş}

Örgütlerin başarıya ulaşabilmeleri kaynaklarını verimli kullanmaları ile sağlanabilir. Bu kaynakların en önemlilerinden biri örgüt çalışanlarıdır. Çalışanları ortak bir amaç etrafında toplamak, aralarındaki işbirliğini sağlayıp onları istekli bir şekilde işe yönlendirecek olanlar ise liderlerdir. Bu bağlamda liderlik, emek yoğun bir hizmet sektörü olarak turizm endüstrisi içinde yer alan konaklama işletmeleri için önemli bir yere sahiptir. Bu işletmelerde hizmetlerde aksaklıkların yaşanmaması için takım çalışması ve iş birliği son derece önemlidir. Konaklama işletmelerinde kaliteli bir hizmet sunmak ve devamını sağlamak, çalışanlarına saygı duyan ve isteklerini bilen, onlar ile iletişimi iyi olan bir lider ile mümkündür (Erol, 2012: 41).

Liderlik teorilerinde liderlerin astlarına karşı belli bir liderlik tarzını sergilediği varsayılmaktadır. Lider-Üye Etkileşimi (LÜE) teorisi ise, liderler ve astları arasındaki ikili ilişkileri temel alması bakımından geleneksel liderlik tarzlarından ayrılır. Böylece liderlerin astları ile karşılıklı etkileşiminde farklı astlar ile farklı etkileşimleri araştırma konusu yapmaktadır (Turgut vd., 2015: 2). İlk defa Dikey İkili Bağlantı Modeli olarak Dansereau vd., (1975) tarafından ileri sürülen ve sonrasında lider-üye etkileşimi adı ile anılmaya başlanan (Dienesch ve Liden, 1986: 618) bu teori, liderlik konusunda yapılan çalışmalara alternatif bir yaklaşım getirmiştir. Dansereau vd., (1975) dikey ikili bağlantı modelinde güvenilir astlar ile liderler arasında ilişkiyi "liderlik ilişkisi", sıradan astlar ile liderler arasındaki ilişkiyi ise "denetim ilişkisi" olarak nitelendirmişlerdir. Dayanak noktasını liderler ve astları arasındaki ikili ilişkilerin oluşturduğu LÜE teorisinde, liderin astlarına karşı davranış tarzında farklılıkların ortaya çıkacağına inanılır (Çekmecelioğlu ve Ülker, 2014: 37). Lider astları ile ilişkilerinde onların her birini dikkate alır ve tüm astlara tek bir liderlik tarzıyla yaklaşmamaya özen gösterir (Arslantaş, 2007: 162).

Konaklama işletmelerinde insan kaynağının etkin kullanımında lider-üye etkileşiminin kalitesi kadar bir başka önemli konu çalışanların örgütlerine olan bağllılı düzeyleridir. Örgütsel bağllılı, bireyi örgüte bağlayan ve örgütten ayrılma olasıllı̆ını azaltan psikolojik durumu ifade etmektedir (Allen ve Meyer, 1990: 14). İşgörenlerin görevlerini yerlerine getirmek için göstermiş oldukları isteklilik ve sahip oldukları kabiliyet işletmelerin devamlılığı açısından tek başına yeterli olamamaktadır. Iş̧letmelerin güçlenerek büyümeleri için işgörenler ile işletme arasında karşılıklı güçlü duygusal bir bağ oluşması gerekmektedir (Bolat ve Bolat, 2008: 76). Bu nedenle nitelikli çalışanları işletmeye kazandırmak kadar bu işgörenleri işletmede tutabilmekte önem arz etmektedir. Konaklama işletmelerinde nitelikli işgörenin kaybedilmesi önemli bir maliyettir. Tekrar aynı niteliklere sahip işgöreni bulup, işgörene gerekli yatırımları yapıp işletmeye alışmasını sağlamak işletme açısından zaman ve maddi kayba neden olmaktadır (Avcı ve Küçükusta, 2009: 36).

Çalışanların iş tatmini müşteriler ile sürekli etkileşim halinde bulunmaları nedeniyle konaklama işletmelerinde diğer önemli bir konu olarak yer almaktadır (Toker, 2007: 92). İş tatmini bireyin işine karşı olumlu duygulara sahip olma durumunu ifade etmektedir (Oshagbemi, 2000: 331). İş tatmini sağlayamayan çalışanlar işlerine adapte olmakta zorluk çekmektedirler. Buna bağlı olarak iş tatmini yüksek olmayan bireylerin müşterilerini memnun eden bir hizmet sunup onları tatmin etmesi de bir o kadar zordur (Alkış, 2008: 64).

Bu çalışmada LÜE Teorisi çerçevesinde konaklama işletmelerinde çalışan işgörenlerin (üyelerinastların) liderleri ile aralarındaki etkileşim düzeyinin kalitesinin işgörenlerin örgütlerine bağlılıkları ve iş tatminleri üzerindeki etkisinin belirlenmesi amaçlanmaktadır. Ulusal ve uluslararası literatür incelendiğinde konaklama işletmelerinde lider-üye etkileşimi ile ilgili gerçekleştirilen birçok çalışma (Kim vd., 2010; Kaşlı ve Aytemiz Seymen, 2010; Bolat, 2011a; Bolat, 2011b; Şahin, 2011; Avcı ve Turunç, 2012; Li vd., 2012; Javaheri vd., 2013; Garg ve Dhar 2014; 
Turunç ve Avcı, 2015; Tanrıverdi ve Kahraman, 2016; Kim vd., 2017; Wang, 2016; Çöp ve Öztürk, 2017; Eşitti, 2017) bulunmasına rağmen lider-üye etkileşiminin çalışanların örgütsel bağl1lıkları ve iş tatminleri üzerindeki etkisini birlikte ele alan ampirik çalışma sayısı son derece kısıtlıdır. Buradan hareketle literatüre katkı sağlayacağı düşüncesi ile gerçekleştirilen bu araştırmada, elde edilen bulgular benzer çalışmalarla karşılaştırılmış ve bundan sonra yapılacak çalışmalar için önerilere yer verilmiştir.

\section{KAVRAMSAL ÇERÇEVE}

\section{Lider-Üye Etkileşimi}

LÜE teorisi, liderler ve astları arasındaki ikili ilişkileri temel alması ve liderler tarafından göz ardı edilen karşılıklı etkileşimi ve farklı astlar ile farklı etkileşimleri araştırma konusu olarak ele almasından dolayı geleneksel liderlik tarzlarından ayrılmaktadır (Turgut vd., 2015: 2). İlk defa Dansereau vd., (1975)'nin dikey ikili bağlantı modeli adıyla ileri sürdügü bu teori son yıllarda lider-üye etkileşimi adı ile anılmaktadır (Dienesch ve Liden, 1986: 618). Dansereau vd., (1975)'e göre dikey ikili bağlantı modelinde güvenilir astlar ile liderler arasında ilişki liderlik ilişkisi; sıradan astlar ile liderler arasındaki ilişki ise denetim ilişkisi ile karakterize edilir. Lider astlarının her biri ile aralarındaki ilişkiyi göz önüne alarak astlarının tümüne tek bir liderlik tarzıyla yaklaşmamaya özen gösterir (Arslantaş, 2007: 162). Teorinin temelini liderler ve astları arasındaki ikili ilişkiler oluşturmaktadır. Buna bağlı olarak liderin astlarına karşı davranış tarzında farklılıkların ortaya çıkacağına inanılır (Çekmecelioğlu ve Ülker, 2014: 37).

Zaman baskısı nedeni ile liderler çalışma gruplarındaki az sayıdaki astları ile samimi ilişkiler, diğerleri ile politika, yetki ve kurallara bağlı olan resmi ilişkiler geliştirmektedirler (Dienesch ve Liden, 1986: 621). Lider ile üyeleri arasındaki ilişkinin kalitesine bağlı olarak üyeler (astlar) iç ve dış grup şeklinde ikiye ayrılmaktadırlar (Graen ve Uhl-Bien, 1995). Liderler az sayıda olan grup içi üyeleri ile resmi iş sözleşmeleriyle sınırlandırılmayan karşılıklı güvenin ve saygının bulunduğu kaliteli ve yakın ilişkiler geliştirmektedirler (Dienesch ve Liden, 1986: 621). Lider iç grupta gördüğü üyesinden görev ve sorumluluklarının ötesinde bir katkı bekler (Liden ve Graen, 1980: 452). İç grupta yer alanlara liderleri diğerlerine göre daha fazla güven duyarlar ve lideri tarafından bu grupta yer alanlar resmi ve gayri resmi olarak daha fazla ödüllendirilirler (Çalışkan, 2009: 221).

Grup içi üyeler liderleri ile yüksek kalitede etkileşim kurmalarından dolayı kariyer gelişimleri de hızlı olmaktadır. Liderler grup dışı üyeleriyle düşük kaliteli ilişkiler kurmaktadırlar. Bunun temel nedeni ise aralarındaki ilişkinin resmi kurallara dayalı olması, karşlıklı güven ve saygı eksikliğinin bulunmasıdır (Turgut vd., 2015: 4). Buna bağlı olarak grup dışı üyeler iş tanımlarında belirtilen işleri yapmak için işe alınmış "eller" şeklinde görülmektedir (Graen ve Uhl-Bien, 1995: 227).

LÜE'ne yönelik yapılan çalışmalarda farklı araştırmacılar tarafından çeşitli boyutlar belirlenmiştir. LÜE'nin boyutlarını ilk olarak Dienesch ve Liden (1986) etki, bağlllık ve katkı olarak ileri sürmüşlerdir. Sonrasında Liden ve Maslyn (1998) tarafından mevcut üç boyuta profesyonel saygı boyutu da eklenmiştir. LÜE boyutları literatürde katkı, bağlılık, etki ve profesyonel sayg1 şeklinde kabul görmektedir (Turgut vd., 2015: 4).

Dienesch ve Liden (1986) katkı boyutunu; "ilişkinin taraflarının ortak amaçlar (açık ya da gizli) için ortaya koydukları iş ile ilgili faaliyetlerin algılanan miktar ve kalitesi" şeklinde tanımlanmıştır. Burada önemli olan nokta astın kendisinden beklenilenden daha fazla iş yapmaya ve lideri için sorumluluk almaya istekli olması ile liderin görevlerin yerine 
getirilmesinde astına sağlamış olduğu kaynaklar ve olanaklardır. Liderin verdiği görevleri yerine getiren astlar liderleri ile daha kaliteli bir etkileşim kurarlar. Üyenin göstermiş olduğu performansı ile liderini etkileyebilmesi sonucunda lideri tarafından asta bütçe, ekipman ve malzeme desteği sağlanır (Liden ve Maslyn, 1998: 45,50; Cevrioğlu, 2007: 41; Baş vd., 2010: 1019).

Dienesch ve Liden (1986)'e göre lider-üye etkileşiminin ikinci boyutu olan bağlllık, lider ve üyenin birbirlerine karşı sadakat derecesidir. Bu kavram her iki tarafında birbirlerinin eylemlerini ve karakterlerini ne ölçüde destekledikleri ile ilgilidir. Bağlllık LÜE'nin sağlanmasında ve devam ettirilmesinde öneme sahip olan kritik bir unsurdur (Liden ve Maslyn, 1998: 46 ).

Etki boyutu, Dienesch ve Liden tarafından "lider ve astı arasındaki, iş veya profesyonel değerlerden daha çok kişiler arasındaki çekiciliğe dayalı karşılıklı ilişki" şeklinde tanımlanmıştır. Etki boyutunun çok az veya hiç öneme sahip olmaması lider-üye ilişkisinin sadece iş odaklı olarak kurulmuş olmasına bağlıdır (Liden ve Maslyn, 1998: 46,50; Baş vd., 2010: 1019).

Profesyonel saygı boyutu, liderin veya astın işindeki uzmanlığından dolayı kurum içinde ve dışında oluşan ününün algılanma derecesini ifade eder. Bu algilama derecesi lider ya da astın kişisel deneyimi, onlar hakkında organizasyon içerisindeki ya da dışarısındaki kişilerin yorumları ve onların mesleki geçmişinde kazandığı ödül ya da profesyonel saygınlık gibi önceki bilgilere dayanabilir. Bu yüzden profesyonel saygı lider ve üyenin birlikte çalışmaları esnasında gelişebildiği gibi lider ve üyenin daha önce karşılaşmamış olmalarına rağmen de gelişebilir (Liden ve Maslyn, 1998: 50).

\section{Örgütsel Bağlılık}

Örgüt ile birey arasında bir bağın oluşabilmesi, bireylerin örgütün ortak değerleri, amaçları ve kültürü çevresinde toplanmalarını bağlllık kavramının özünde yatan "aidiyet duygusu" sağlamaktadır. Aidiyet duygusuna bağlı olarak, örgütsel verimin artmasında, bireyin kendini örgütle birlikte tanımlayıp özdeşleştirmesinde, örgütteki değişimi kabullenme derecesinde, bireyin üretkenliğinde ve iş gücü devir oranında örgütsel bağlllık kavramının etkisi bulunmaktadır (Sığrı, 2007: 262).

İlk olarak Whyte tarafından 1956 yılında ele alınmış olan örgütsel bağlılık kavramı sonraki zamanlarda pek çok araştırmacı (Becker, Porter, Mowday, Steers, Allen, Meyer) tarafından geliştirilmiştir (Gül, 2002: 37). Örgütsel bağlllık literatürüne bakıldığında, bağlılık kavramının farklı biçimlerde kullanılmasından dolayı farklı tanımlarının ortaya çıktığı görülmektedir (Balay, 2014: 17). Örgütsel bağlllığın farklı tanımlarının olmasının nedeni; örgütsel davranış, örgütsel psikoloji ve sosyal psikoloji alanlarından gelen araştırmacıların konuya kendi bakış açılarıyla yaklaşmalarıdır (Gül, 2002: 38). Başlıca tanımlara bakıldığında;

Örgütsel bağll1ığı Weiner (1982: 418), örgütsel menfaatleri karşılayacak şekilde hareket etmek için benimsenmiş normatif baskıların bütünü; Buchanan (1974: 533), bireyin örgütün amaç ve değerlerine kendi yararından çok örgütün yararına olacağından dolayı duygusal anlamda bağlanması; Mowday vd., (1979: 226), kişinin belirli bir örgütle özdeşleşmesi ve bir örgüte katılımının göreceli gücü; Allen ve Meyer (1990: 14) ise, bireyi örgüte bağlayarak ayrılma ihtimalini azaltan psikolojik durum şeklinde tanımlamıştır.

Örgütsel bağlllık literatürü incelendiğginde örgütsel bağlllı̆̆ın boyutlarının farklı araştırmacılar tarafından farklı şekillerde belirlendiği görülmektedir. Etzioni örgütsel bağlılığı, yabancılaştırıcı, çıkara dayalı ve ahlaki bağlılık (Balay, 2014: 25); Kanter (1968: 500), devama yönelik, kenetlenme ve kontrol bağlılığı; O'Reilly ve Chatman ise uyum, özdeşleşme ve içselleştirme bağlılığı olarak 
belirlemiştir (Balay, 2000: 18). Literatürde genel olarak kabul gören örgütsel bağlllık boyutları ise duygusal bağll1ık, devam bağl1lı̆̆1 ve normatif bağlılıktır (Allen ve Meyer, 1990: 3).

Allen ve Meyer örgütsel bağlılığı, bireylerin örgütle olan ilişkilerine bağlı olarak şekillenen, örgüt üyeliğinin sürdürme veya sonlandırma kararlarını etkileyen psikolojik bir durum olduğunu ifade etmişler ve örgütsel bağl1lığ üç boyutta ele almışlardır (Allen ve Meyer, 1990: 2-5; Meyer ve Allen, 1991: 67; Meyer vd., 1998: 32; Balay, 2000: 27).

Duygusal bağlılık, kendisini örgütün bir parçası olarak gören işgörenlerin örgüte karşı duygusal olarak bağlanmalarını ifade etmektedir. Duygusal bağlılığa sahip olan çalışanlar ihtiyaç olarak hissettiklerinden dolayı değil istediklerinden dolayı örgütte kalmayı sürdürürler (Meyer ve Allen, 1991: 67).

Devam bağlılığı, çalışanların örgütlerine yaptıkları yatırımlara bağlı olarak oluşur. Devam bağlılığının oluşmasında bir iş görenin örgütte geçirdiği zaman zarfı içerisinde örgüt için harcadığ1 zamanı, örgüt için verdiği çaba ve emeği, elde ettiği pozisyon ve maaş gibi kazanımlarını göz önünde bulundurarak örgütten ayrılması durumunda bu kazanımlarını kaybedeceğini düşünmesi etkilidir (Yalçın ve İplik, 2005: 398 ).

Normatif bağll1lk, bireyin örgütte çalışmaya başlamadan önce ve örgütte geçirdiği süre içerisinde yaşadıklarına bağlı olarak örgütte kalma konusunda baskı hissetmesi sonucunda oluşur (Allen ve Meyer, 1990: 4). Bireyin kişisel çıkarları için değil, örgütte kalmanın doğru ve ahlaki olduğuna inanması nedeniyle örgütte kalmak istemesiyle ortaya çıkan bir bağlılıktır (Balay, 2014: 28).

\section{İş Tatmini}

Bireyler iş yaşamlarında istedikleri işlerle uğraştıklarında, bilgi ve yeteneklerini kullandıklarında verimlilikleri artmakta ve ihtiyaçlarını karşılayabilmektedirler. İsteklerini karşılayamayan bireylerde iş doyumsuzluğu meydana gelmektedir. İş görenlerin iş tatmini sağlayabilmeleri için iş görenlerin morallerinin yüksek tutulması, sevdikleri işleri yapmaları, iş görenlere yetki ve sorumluluk verilmesi, yaratıcı düşüncelerine saygı duyulması, bilgi ve becerilerini kullanmalarına olanak sağlanması gerekmektedir (Toker, 2006: 144).

Oshagbemi (2000: 331) iş tatminini bireyin işine karşı olumlu duygusal tepkileri şeklinde tanımlamaktadır. Bir başka tanıma göre iş tamini; bir kişinin iş deneyiminden ya da bir kurum ile bir kişi arasındaki uyumdan kaynaklanan olumlu bir tutum veya zevkli duygusal bir durumdur (Ugboro ve Obeng, 2000: 253-254).

Literatürde iş tatmininin sistematik olarak incelenmesi ilk olarak motivasyon kuramları ile başlamıştır (Toker, 2007: 94). Bu kuramlar kapsam ve süreç kuramları olarak ikiye ayrılmaktadır. Kapsam kuramlarının başlıcaları Maslow'un İhtiyaçlar Hiyerarşisi Kuramı, Alderfer'in ERG Kuramı, Herzberg'in Çift Etken Kuramı ve Mc Clelland'ın Başarma İhtiyacı Kuramıdır. Süreç kuramlarının başlıcaları ise Beklenti kuramları, Pekiştirme kuramı, Eşitlik kuramı ve Amaç kuramidır (Toker, 2006: 86).

İş tatmini ile ilgili literatür incelendiğinde iş görenlerin iş tatminleri üzerinde etkisi olan birçok faktörün bulunduğu görülmektedir. Bu faktörler arasında yaş ve deneyim, cinsiyet, kişilik özellikleri, meslek ve iş konumu, eğitim düzeyi gibi bireysel faktörler; örgütün büyüklügü, ücret, çalışma şartları, yönetim biçimi, terfi olanakları ve çalışma arkadaşları gibi örgütsel faktörler siralanabilir (Clark vd., 1996; Oshagbemi, 2000; Toker, 2007; Bozkurt ve Bozkurt, 2008; İşcan ve Sayın, 2010). 


\section{Araştırma Değişkenleri Arasındaki İlişkiler}

Literatürde LÜE'nin örgütsel bağlılık ve iş tatmini üzerindeki etkisini inceleyen çok sınırlı sayıda çalışma bulunmasına rağmen (Çekmecelioğlu ve Ülker, 2014), LÜE ve örgütsel bağlılık arasındaki ilişkiyi (Kinicki ve Vecchio, 1994; Joo, 2010; Göksel ve Aydıntan, 2012; Casimir vd., 2014) ve LÜE ile iş tatmini arasındaki ilişkiyi (Janssen ve Van Yperen, 2004; Laschinger vd., 2007; Akkoç ve Çiftçi, 2016; Uçar, 2019) inceleyen birçok çalışmanın bulunduğu görülmektedir. Konaklama işletmeleri özelinde ise LÜE ve örgütsel bağlllık arasındaki ilişkiyi inceleyen az sayıda çalışma mevcutken (Garg ve Dhar, 2014; Kim vd., 2017), LÜE ve iş tatmini arasındaki ilişkiyi ele alan bir çalışmaya literatür taramasında erişilememiştir. Bununla birlikte, yapılan çalışmalar sonucunda genel olarak lider-üye etkileşiminin iş görenlerin örgütsel bağlılıklarını (Göksel ve Aydıntan, 2012; Garg ve Dhar, 2014; Kim vd., 2017) ve iş tatminlerini (Janssen ve Van Yperen, 2004; Akkoç ve Çiftçi, 2016) pozitif yönde etkilediği sonucuna ulaşılmıştır.

\section{YÖNTEM}

\section{Araştırmanın Amacı, Evreni ve Örneklemi}

Çalışanlarına istihdam ve gelir sağlaması bakımından turizm endüstrisi içerisinde önemli bir yere sahip olan konaklama işletmelerinin başarısı büyük oranda işgörenin verimliliğine bağlıdır. Bu bağlamda konaklama işletmelerinin başarısında önemli rol oynayan işgörenler ile onların liderleri arasındaki ilişki önem arz etmektedir. Bu noktadan hareketle araştırmanın amacı liderüye etkileşimi teorisi çerçevesinde konaklama işletmelerinde çalışan iş görenlerin liderleri ile aralarındaki etkileşim düzeyinin kalitesinin iş görenlerin örgütlerine bağlllıkları ve iş tatminleri üzerindeki etkisinin belirlenmesidir.

$\mathrm{Bu}$ çalışmada nicel araştırma yöntemi kullanılmıştır. Araştırma konusu dikkate alınarak konaklama işletmelerinin genel olarak yıl boyu faaliyet göstermeleri ve daha kurumsal bir yapıda oldukları düşüncesi ile çalışmanın evrenini Antalya Belek bölgesinde yer alan beş yıldızlı konaklama işletmelerinin çalışanları oluşturmaktadır. Antalya İl Kültür ve Turizm Müdürlüğü (2010) tarafından hazırlanan Yatırım ve İşletme Belgeli Konaklama Tesislerinin İlçeler Bazında Dağılımı Tablosuna göre, Antalya Belek Bölgesinde bulunan işletme belgeli 49 adet beş yıldızlı konaklama tesisinde toplam 43.914 yatak kapasitesin bulunduğu belirlenmiştir. Buradan hareketle beş yıldızlı bir konaklama işletmesinde ortalama $896.2 \cong 900$ yatak kapasitesi olduğu sonucuna ulaşlabilir. Kültür ve Turizm Bakanlığı (2018) turizm işletme belgeli tesis istatistiğine göre Belek Bölgesinde beş yıldızlı 51 adet konaklama işletmesi bulunduğundan araştırma döneminde Belek bölgesinde toplam 45.714 yatak kapasitesi mevcuttur. Türkiye Otelciler Fedarasyonu (2010) Turizm Raporu'na göre beş yıldızlı konaklama işletmelerinde bir çalışana 3,08 yatak düşmektedir. Dolayısıyla araştırma evreninin yaklaşık 14.842 çalışandan oluştuğu söylenebilir. Bu bilgiler ışığında, hedef kitledeki birey sayısının bilindiği durumdaki örneklem büyüklüğü $\mathrm{n}=\mathrm{Nt}^{2}$.p.q/d2(N-1)+ $\mathrm{t}^{2}$.p.q formülünden yararlanılarak 375 olarak hesap edilmiştir (Baş, 2006: 45).

\section{Verilerin Toplanması ve Analizi}

Çalışmada lider-üye etkileşimi düzeyini ölçmek amacıyla Liden ve Maslyn tarafından 1998 yılında geliştirilmiş olan "Çok Boyutlu Lider-Üye Etkileşimi12" (LMX-MDX 12) ölçeği kullanılmıştır. Araştırmada çalışanların örgütsel bağlılık düzeylerini ölçmek için Meyer ve Allen (1991)'nin geliştirdiği örgütsel bağlllık ölçeğinin daha sonra Meyer, Allen ve Smith (1993) tarafından tekrar düzenlenen şekli kullanılmıştır. Çalışanların iş tatmini düzeylerini ölçmek için 
ise Yoon ve Thye (2002)'nin Brayfield ve Rothe (1951) tarafından geliştirilen iş tatmini ölçeğinin ifadelerinden yararlanarak oluşturdukları tek boyutlu ve beş ifadeden oluşan iş tatmini ölçeği kullanılmıştır.

Araştırma 2018 yılı Mayıs-Ekim ayları arasında Antalya Belek bölgesinde gerçekleştirilmiştir. Önce 2 adet 5 yıldızlı otel işletmesinde toplam 66 çalışanla ön test yapılmıştır. Ön test sonunda ölçeklerin güvenilirlik katsayıları sırasıyla; LÜE ölçeği 0.93, Örgütsel bağlılık ölçeği 0.76 ve iş tatmini için 0.88 olarak elde edilmiştir. Ayrıca anketlerde anlaşılmasında güçlük çekilen bir ifadeye rastlanmadığından anket soruları üzerinde bir değişiklik yapılmamıştır.

Verilerin elde edilmesinde kolayda örnekleme yöntemi kullanılmış olup, araştırmaya katılmayı kabul eden 11 adet beş yıldızlı konaklama işletmesindeki tanıdık yöneticiler ve çalışanlar vasıtası ile 526 adet anket toplanmıştır. Belirlenen örneklemin üzerinde anket toplanmasına rağmen verilerin analizinden önce yapılan incelemede 207 anketin analize uygun şekilde doldurulmadığ 1 tespit edilmiştir. Bundan dolayı bu anketler değerlendirme dışı bırakılarak geri kalan 319 anket analize tabi tutulmuştur.

Analizden önce verilerin normal dağılıp dağılmadığını görmek ve uygulanacak test türünün parametrik olup olmayacağına karar vermek için normallik testi uygulanmıştır. Test sonucunda; kullanılan ölçeklerin basıklık ve çarpıklık değerlerinin sırasıyla; LÜE Ölçeği için $(0.648 ;-1.133)$, Örgütsel Bağlllık Ölçeği için $(-0.466 ;-0.085)$ ve İş Tatmini Ölçeği için $(1.898 ;-1.156)$ olduğu belirlenmiştir. Elde edilen çarpıklık ve basıklık katsayı değerlerinin tamamının literatürde kullanılan kritik değerler (+2.58) ve (-2.58) arasında olduğu görülmüştür (Hair vd., 2014: 71). Buna göre verilerin normal dağılıma sahip olduğu söylenebilir. Sonrasında verilere korelasyon ve çoklu regresyon analizleri uygulanmıştır.

\section{BULGULAR}

Araştırmaya katılanların demografik özellikleri incelendiğinde; katılımcıların \%56.4'ü erkek, \%43.6'sı kadın olup, çoğunluğu (\%64.9) evli, eğitim durumlarına göre; \%44.8'i lise, \%15.4'ü ilk öğretim, \%19.7'si ön lisans, \%18.5'i lisans ve \%1.6'sı ise lisansüstü mezunudur. Katılımcıların \%32'si yiyecek İçecek, \%23.5'i kat hizmetleri, \%12.5'i önbüro, \% 6.9'u insan kaynakları, \%6.6's1 satış pazarlama, \%5.3'ü güvenlik, \%6.3'ü muhasebe ve \%6.9'u diğer departmanlarda çalışmaktadır. 319 katılımonın \%16.3'ü 25 ve altı yaş aralığında iken, büyük çoğunluğu (\%76.5) 26 ve 40 yaş aralığında, \%4.4'ü $41-45$ yaş ve \%2.8'i ise 46 yaş ve üzerindedir. Katılımcıların çalıştıkları işletmelerdeki görev sürelerine bakıldığında; \%16.6'sı 1 yıldan az süredir, \%45.8'i 1-5 yıl aralığında, \%32.3'ü 6-10 yıl aralığında, \%5.3'ü 11 yıl ve üzerinde işletmelerinde çalışmaktadır. Son olarak çalışma şekilleri bakımından katılımcıların çoğunluğunun (\%78.7) sürekli olarak, \%21.3'ünün ise sezonluk olarak işletmelerinde çalıştıkları belirlenmiştir. Araştırma kapsamında elde edilen anket formlarındaki diğer verilerin analizlerine ilişkin tablolar ve yorumları aşağıda yer almaktadir.

\section{Faktör Analizine İlişkin Bulgular}

Araştırma kapsamında kullanılan lider-üye etkileşimi ölçeğine ait faktör analizi Tablo 1'de görülmektedir. Örgütsel bağlllık ölçeğine ait faktör analizine Tablo 2'de ve iş tatmini ölçeğine ait faktör analizine ise Tablo 3 'te yer verilmiştir. 
Tablo 1. Lider-Üye Etkileşimi Ölçeğine Ait Faktör Analizi Tablosu

\begin{tabular}{|c|c|c|c|c|c|}
\hline & $\begin{array}{l}\text { Faktör } \\
\text { Yükleri }\end{array}$ & $\begin{array}{l}\text { Öz } \\
\text { Değerler }\end{array}$ & $\begin{array}{l}\text { Açıklanan } \\
\text { Varyans (\%) }\end{array}$ & Ortalama & $\begin{array}{l}\text { Güvenilirlik } \\
(\alpha)\end{array}$ \\
\hline Faktör 1: Profesyonel Sayg1 & & 2.686 & 22.382 & 4.19 & 0.923 \\
\hline $\begin{array}{l}\text { 10. Amirimin mesleki becerilerine } \\
\text { hayranlık duyarım. }\end{array}$ & 0.792 & & & & \\
\hline $\begin{array}{l}\text { 11.Amirimin iş ile ilgili bilgi ve } \\
\text { yeterliliğine saygı duyarım }\end{array}$ & 0.784 & & & & \\
\hline $\begin{array}{l}\text { 12. Amirimin iş ile ilgili } \\
\text { bilgisinden etkilenirim. }\end{array}$ & 0.776 & & & & \\
\hline Faktör 2: Katk1 & & 2.657 & 22.145 & 4.22 & 0.875 \\
\hline $\begin{array}{l}\text { 9. Amirim için iş tanımımda } \\
\text { belirtilenden daha fazla bir görevi } \\
\text { yaparım. }\end{array}$ & 0.842 & & & & \\
\hline $\begin{array}{l}\text { 8.Amirimin işe yönelik } \\
\text { hedeflerini karşılamak için } \\
\text { normalde istenenden daha fazla } \\
\text { çaba göstermeye razıyım. }\end{array}$ & 0.727 & & & & \\
\hline $\begin{array}{l}\text { 7.Amirim için elimden gelenin en } \\
\text { iyisini yapmayı sorun etmem. }\end{array}$ & 0.680 & & & & \\
\hline Faktör 3:Etki & & 2.480 & 20.665 & 4.15 & 0.923 \\
\hline $\begin{array}{l}\text { 2.Amirim herhangi bir insanın } \\
\text { arkadaş olmayı isteyeceği bir } \\
\text { kişidir. }\end{array}$ & 0.753 & & & & \\
\hline $\begin{array}{l}\text { 3.Amirim ile çalışmak çok } \\
\text { eğlencelidir. }\end{array}$ & 0.729 & & & & \\
\hline $\begin{array}{l}\text { 1.Amirimi kişi olarak çok } \\
\text { severim. }\end{array}$ & 0.708 & & & & \\
\hline Faktör 4: Bağlılık & & 2.176 & 18.136 & 4.13 & 0.850 \\
\hline $\begin{array}{l}\text { 4. Amirim yaptığım işleri, } \\
\text { gündemdeki konu ile ilgili tam } \\
\text { bilgi sahibi olmasa bile üstüne } \\
\text { karşı savunur. }\end{array}$ & 0.824 & & & & \\
\hline $\begin{array}{l}\text { 5. Başkaları üzerime gelirse } \\
\text { amirim beni onlara karşı savunur. }\end{array}$ & 0.706 & & & & \\
\hline $\begin{array}{l}\text { 6. Ĕ̆gr mazur görülebilir bir hata } \\
\text { yaparsam, amirim beni işletmede } \\
\text { başkalarına karşı savunur. }\end{array}$ & 0.527 & & & & \\
\hline
\end{tabular}

Lider-Üye Etkileşimi ölçeğinin güvenilirlik katsayısı 0.956 olarak tespit edilmiştir. Daha sonra elde edilen verilere özdeğer yöntemi ile bir faktör sinırlaması getirilmeden faktör analizi uygulanmıştır. Analiz sonucunda tüm önermelerin tek bir faktör altında toplandığı görülmüştür. Ancak ölçeğin 4 faktörden oluşması nedeniyle varimax döndürme yöntemi kullanılarak 4 faktörle sınırlandırılıp faktör analizi tekrarlanmıştır. Bu faktör analizi sonucunda 12 önermenin literatüre uygun olarak "profesyonel saygı", "katkı", "etki" ve "bağlllık" olarak adlandırılan 4 faktör altında toplandığı görülmüştür (Tablo 1). 
Tablo 2. Örgütsel Bağlllık Ölçeğine Ait Faktör Analizi Tablosu

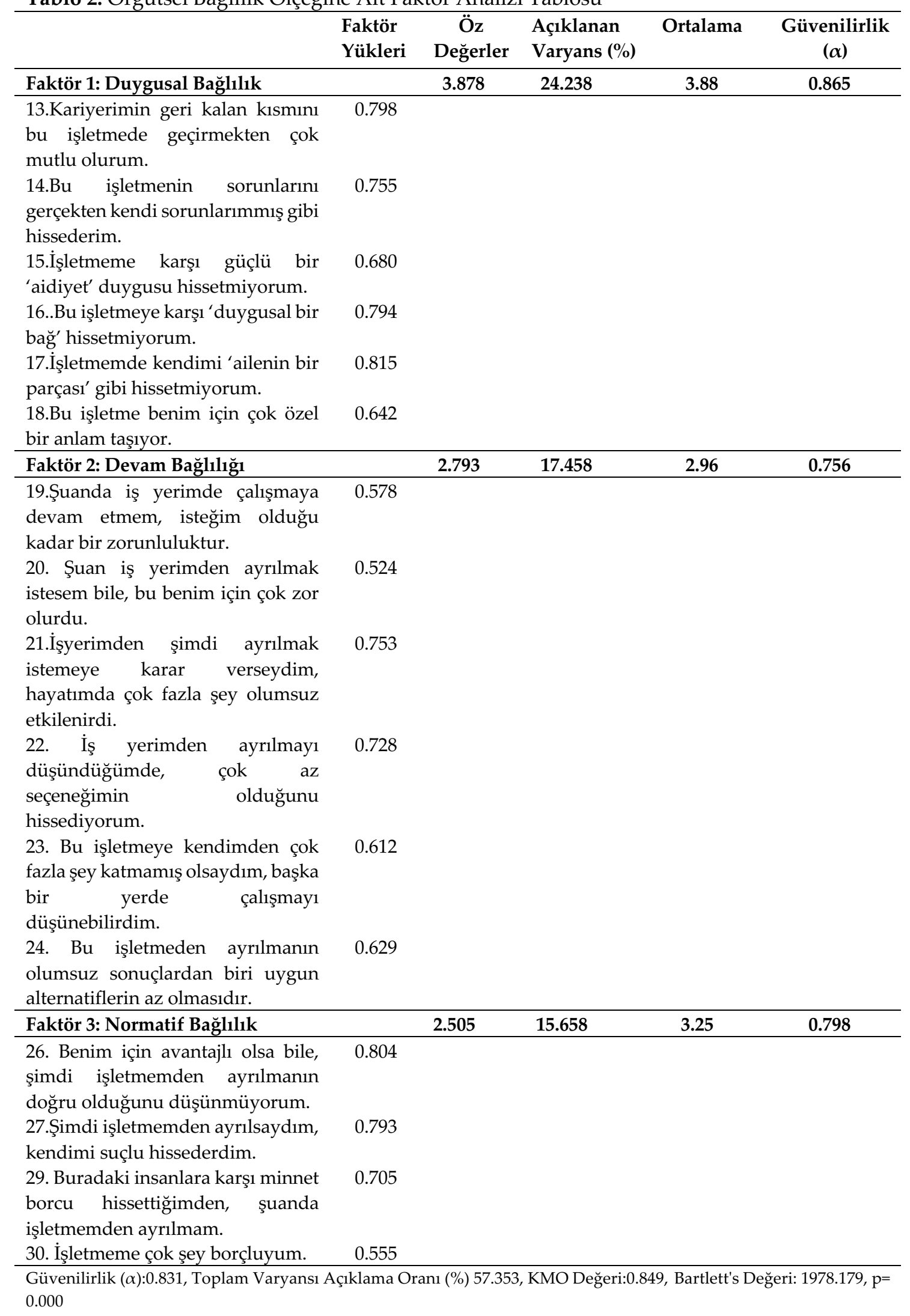


18 önermeden oluşan örgütsel bağlllık ölçeğinin güvenilirlik katsayısı 0.831 olarak tespit edilmiştir. Özdeğer yöntemi ile faktör sınırlaması olmadan yapılan faktör analizi sonucunda 4 faktörlü bir yapı oluşmuştur. Örgütsel bağlılık ölçeği 3 faktörden oluştuğu için varimax döndürme yöntemi kullanılarak 3 faktörle sınırlandırılıp faktör analizi tekrarlanmıştır. Analizi sonucunda 25. önerme faktör analizinde tek kaldığından ve 28. önerme farklı bir faktör altında yer aldığından faktör analizinden çıkartılmıştır. Tekrarlanan faktör analizi sonucunda ölçeğin faktör yapısı literatür ile benzerlik göstermiş ve sırasıyla; "duygusal bağlılık", "devam bağlıllığı" ve "normatif bağlılık" olarak adlandırılan 3 faktör ortaya çıkmıştır (Tablo 2).

Tablo 3. İş Tatmini Ölçeğine Ait Faktör Analizi Tablosu

\begin{tabular}{|c|c|c|c|c|c|}
\hline & $\begin{array}{l}\text { Faktör } \\
\text { Yükleri }\end{array}$ & $\begin{array}{l}\text { Öz } \\
\text { Değerler }\end{array}$ & $\begin{array}{l}\text { Açıklanan } \\
\text { Varyans } \\
(\%)\end{array}$ & Ortalama & $\begin{array}{l}\text { Güvenilirlik } \\
(\alpha)\end{array}$ \\
\hline Faktör 1 & & 3.436 & 68.724 & 4.07 & 0.864 \\
\hline 31. İşimden keyif alıyorum. & 0.851 & & & & \\
\hline $\begin{array}{l}\text { 32. Sık sık işimin çok iyi olduğunu } \\
\text { düşünüyorum. }\end{array}$ & 0.892 & & & & \\
\hline 33. Şu anki işimi seviyorum. & 0.897 & & & & \\
\hline 34. İşimden memnunun. & 0.880 & & & & \\
\hline 35. İşime karşı ilgimi kaybediyorum. & 0.582 & & & & \\
\hline
\end{tabular}

İş tatmini ölçeği 5 ifadeden oluşmaktadır. Ölçeğin güvenilirlik katsayısı 0.864 olarak tespit edilmiştir. Özdeğer yöntemi kullanılarak ve faktör sınırlaması olmadan uygulanan faktör analizinde tüm önermeler tek faktör altında toplanmıştır (Tablo 3).

\section{Korelasyon Analizi}

LÜE ile örgütsel bağlılık ve iş tatmini düzeyleri arasındaki ilişkileri incelemek üzere korelasyon analizi gerçekleştirilmiştir. Tablo 4'e göre lider-üye etkileşiminin alt boyutları ile örgütsel bağlılığın alt boyutları arasındaki ilişkiler incelendiğinde, en yüksek korelasyon kat sayısının LÜE'nin profesyonel saygı alt boyutu ile örgütsel bağlılığın duygusal bağlılık alt boyutu arasında $(\mathrm{r}=0.530)$ olduğu görülmektedir LÜE alt boyutları ile iş tatmini arasında ise, genel olarak orta ve pozitif yönlü bir ilişki görülmekle birlikte, en yüksek düzeydeki ilişkinin "etki boyutu" ile" iş tatmini" arasında $(\mathrm{r}=0.545)$ olduğu belirlenmiştir.

Tablo 4. Lider-Üye Etkileşimi İle Örgütsel Bağlılık ve İş Tatmini Düzeyleri Arasındaki Korelasyon Tablosu

\begin{tabular}{|c|c|c|c|c|c|}
\hline & & Duygusal Bağlilık & Devam Bağlılığg & Normatif Bağlılık & İş Tatmini \\
\hline \multirow[t]{2}{*}{ Etki } & $\mathrm{r}$ & $0.517^{* *}$ & 0.007 & $0.316^{* *}$ & $0.545^{* *}$ \\
\hline & $\mathrm{p}$ & 0.000 & 0.907 & 0.000 & 0.000 \\
\hline \multirow[t]{2}{*}{ Bağlılık } & $\mathrm{r}$ & $0.463^{* *}$ & 0.080 & $0.320^{* *}$ & $0.530^{* *}$ \\
\hline & $\mathrm{p}$ & 0.000 & 0.155 & 0.000 & 0.000 \\
\hline \multirow[t]{2}{*}{ Katk1 } & $\mathrm{r}$ & $0.492^{* *}$ & 0.079 & $0.318^{* *}$ & $0.511^{* *}$ \\
\hline & $\mathrm{p}$ & 0.000 & 0.160 & 0.000 & 0.000 \\
\hline Profesyon & $\mathrm{r}$ & $0.530^{* *}$ & 0.031 & $0.339^{* *}$ & $0.529^{* *}$ \\
\hline el Sayg1 & $\mathrm{p}$ & 0.000 & 0.576 & 0.000 & 0.000 \\
\hline
\end{tabular}

** $\mathrm{p}<0.01$ 


\section{Regresyon Analizi}

Araştırma kapsamında lider-üye etkileşiminin dört boyuttan oluşması yani birden fazla bağımsız değişkene sahip olması nedeniyle verilere çoklu regresyon analizi uygulanmıştır. Analiz sonuçları Tablo 5-Tablo 8' de verilmiştir.

Tablo 5. Lider-Üye Etkileşiminin Duygusal Bağlllık Üzerindeki Etkisine Yönelik Çoklu Regresyon Analizi

\begin{tabular}{lccccc}
\hline \multicolumn{5}{c}{ Duygusal Bağlılık } \\
\hline & $\mathrm{B}$ & Standart Hata & $\beta$ & $\mathrm{t}$ & $\mathrm{P}$ \\
\hline Sabit & 1,607 & 0.202 & - & 7.944 & 0.000 \\
Etki & 0.149 & 0.078 & 0.177 & 1.913 & 0.057 \\
Bağl1lık & 0.021 & 0.077 & 0.023 & 0.275 & 0.783 \\
Katk1 & 0.136 & 0.073 & 0.146 & 1.875 & 0.062 \\
Profesyonel Sayg1 & 0.237 & 0.069 & 0.271 & 3.449 & $\mathbf{0 . 0 0 1}$ \\
\hline R= 0.564 $\mathrm{R}^{2}=0.318$ Düzeltilmiş $\mathrm{R}^{2}=0.309 \mathrm{~F}=$ 36.586 Durbin-Watson= $1.715 \mathrm{p}=0.000$ & &
\end{tabular}

Tablo 5'de verilen duygusal bağlılı̆̆ın sabit değişken olarak alındığı ilk regresyon analizi sonuçlarında, lider-üye etkileşiminin sadece profesyonel saygı boyutunun örgütsel bağlllığın duygusal bağlılık boyutu üzerinde anlamlı pozitif etkisinin olduğu tespit edilirken $(\beta: 0.271 ; \mathrm{p}<$ 0.05); lider-üye etkileşiminin diğer alt boyutlarının örgütsel bağlılı̆̆ın duygusal bağlllık boyutu üzerinde anlamlı bir etkisi bulunamamıştır ( $p>0.05)$.

Tablo 6. Lider-Üye Etkileşiminin Devam Bağlılığı Üzerindeki Etkisine Yönelik Çoklu Regresyon Analizi

\begin{tabular}{|c|c|c|c|c|c|}
\hline \multicolumn{6}{|c|}{ Devam Bağlılığı } \\
\hline & $\mathrm{B}$ & Standart Hata & $\beta$ & $\mathrm{t}$ & $\mathrm{P}$ \\
\hline Sabit & 2,613 & 0.240 & - & 10,890 & 0.000 \\
\hline Etki & -0.176 & 0.092 & -0.212 & $-1,907$ & 0.057 \\
\hline Bağlılık & 0.149 & 0.091 & 0.161 & 1,636 & 0.103 \\
\hline Katk1 & 0.120 & 0.086 & 0.130 & 1,392 & 0.165 \\
\hline Profesyonel Sayg1 & -0.010 & 0.082 & -0.011 & -0.119 & 0.905 \\
\hline
\end{tabular}

$\mathrm{R}=0.146 \mathrm{R}^{2}=0.021$ Düzeltilmiş $\mathrm{R}^{2}=0.009 \mathrm{~F}=1.715$ Durbin-Watson=1.788 $\mathrm{p}=0.146$

Sabit değişken olarak devam bağlılığının alındığı analizde (Tablo 6), lider-üye etkileşiminin hiçbir boyutunun örgütsel bağlllığın devam bağlllığı boyutu üzerinde anlamlı bir etkisinin olmadığı sonucuna ulaşılmıştır ( $\mathrm{p}>0.05)$.

Tablo 7. Lider-Üye Etkileşiminin Normatif Bağlılık Üzerindeki Etkisine Yönelik Çoklu Regresyon Analizi

\begin{tabular}{|c|c|c|c|c|c|}
\hline \multicolumn{6}{|c|}{ Normatif Bağlılık } \\
\hline & B & Standart Hata & $\beta$ & $t$ & $\mathrm{P}$ \\
\hline Sabit & 1.883 & 0.206 & - & 9.137 & 0.000 \\
\hline Etki & 0.012 & 0.079 & 0.015 & 0.146 & 0.884 \\
\hline Bağlılık & 0.091 & 0.078 & 0.108 & 1.164 & 0.245 \\
\hline Katk1 & 0.083 & 0.074 & 0.099 & 1.124 & 0.262 \\
\hline Profesyonel Sayg1 & 0.142 & 0.070 & 0.180 & 2.022 & 0.044 \\
\hline
\end{tabular}

$R=0.363 R^{2}=0.132$ Düzeltilmiş $R^{2}=0.120 F=11.889$ Durbin-Watson= $1.675 p=0.000$ 
Lider-üye etkileşiminin normatif bağlılık üzerindeki etkisine yönelik analiz sonuçlarında (Tablo 7); LÜE alt boyutlarından sadece profesyonel saygı boyutunun normatif bağll1ık boyutu üzerinde anlamlı pozitif etkisinin olduğu görülürken ( $\beta$ :0.180: $p<0.05)$, etki, bağlılık ve katkı boyutlarının ise örgütsel bağllı̆̆ın normatif bağlllık boyutu üzerinde anlamlı bir etkisi bulunamamıştır ( $\mathrm{p}>$ 0.05).

Tablo 8. Lider-Üye Etkileşiminin İş Tatmini Üzerindeki Etkisine Yönelik Çoklu Regresyon Analizi

\begin{tabular}{lccccc}
\hline & \multicolumn{5}{c}{ İş Tatmini } \\
\hline & $\mathrm{B}$ & Standart Hata & $\beta$ & $\mathrm{t}$ & $\mathrm{P}$ \\
\hline Sabit & 1.660 & 0.197 & - & 8.429 & 0.000 \\
Etki & 0.139 & 0.076 & 0.166 & 1.829 & 0.068 \\
Bağl1lık & 0.165 & 0.075 & 0.177 & 2.203 & $\mathbf{0 . 0 2 8}$ \\
Katk1 & 0.112 & 0.071 & 0.121 & 1.538 & 0.114 \\
Profesyonel Sayg1 & 0.163 & 0.067 & 0.187 & 2.429 & $\mathbf{0 . 0 1 4}$ \\
\hline
\end{tabular}

$\mathrm{R}=0.588 \mathrm{R}^{2}=0.345$ Düzeltilmiş $\mathrm{R}^{2}=0.337 \mathrm{~F}=41.393$ Durbin-Watson= $1.862 \mathrm{p}=0.000$

Tablo 8'de LÜE'nin iş tatmini üzerindeki etkisini belirlemek için yapılan analiz sonucunda; bağlılık ve profesyonel saygı boyutlarının iş tatmini üzerinde anlamlı pozitif etkisinin olduğu ( $\beta$ : 0.177, B:0.187; $p<0.05)$, etki ve katkı boyutlarının ise iş tatminini anlamlı bir şekilde etkilemediği ( $p>0.05)$ görülmektedir.

Araştırma bulguları bir bütün olarak ele alındığında, literatürde daha önce gerçekleştirilen çalışmalarla paralellik göstermektedir. Bununla birlikte, lider-üye etkileşiminin örgütsel bağlllık üzerindeki etkisini araştırma değişkenlerinin boyutları itibari ile ele alan benzer bazı araştırmaların (Çekmecelioğlu ve Ülker, 2014; Göksel ve Aydıntan, 2012) bulguları ile bu çalışmanın bulguları arasında farklılıklar olduğu belirlenmiştir.

\section{TARTIŞMA ve SONUÇ}

$\mathrm{Bu}$ araştırmada konaklama işletmelerindeki astlar (işgörenler) ile liderleri arasındaki etkileşimin önemine vurgu yapılmış ve bu etkileşimin kalitesinin onların örgütsel bağlılıkları ve iş tatminleri üzerinde bir etkisinin olup olmadığı belirlenmeye çalışılmıştır. Araştırma sonucunda Antalya Belek bölgesindeki konaklama işletmeleri çalışanlarının liderleri ile olan etkileşimlerinin yüksek seviyede olduğu söylenebilir. Bu çalışanların işletmelerine karşı duygusal bağlllıklarının yüksek, devam bağlılıklarının ise düşük seviyede olduğu tespit edilmiştir.

Regresyon analizleri sonucunda; profesyonel saygı boyutunun örgütsel bağlılığın hem duygusal bağlılık hem de normatif bağlllık alt boyutları üzerinde etkisi bulunan tek lider-üye etkileşimi alt boyutu olduğu sonucuna ulaşılmıştır. Çekmecelioğlu ve Ülker (2014) tarafından eğitim kurumlarında öğretmenler ile gerçekleştirilen çalışmada ise LÜE'nin bağlılık ve profesyonel saygı boyutlarının duygusal bağlılık üzerinde, bağlılık ve katkı boyutlarının normatif bağlllık üzerinde pozitif etkisinin olduğu sonucuna ulaşılmıştır. Göksel ve Aydıntan (2012) tarafından hastanelerdeki başhemşireler ile gerçekleştirilen çalışmada ise LÜE'nin sadece bağlllık alt boyutunun duygusal ve normatif bağllık üzerinde pozitif etkisinin bulunduğu tespit edilmiştir. Bu bağlamda bireylerin çalıştıkları sektörlere bağlı olarak örgütsel bağlılıklarını etkileyen liderüye etkileşimi alt boyutlarının farklılık gösterebileceği sonucuna ulaşılabilir. Ayrıca analiz sonucunda, LÜE'nin hiçbir alt boyutunun örgütsel bağlılığın devam bağlılığı boyutu üzerinde bir etkisinin olmadığı belirlenmiştir. 
LÜE ile iş tatmini arasındaki ilişkide, LÜE'nin bağlılık ve profesyonel saygı boyutlarının iş tatmini üzerinde pozitif etkisinin olduğu sonucuna ulaşılmıştır. Elde edilen bu sonuç Akkoç ve Çiftçi (2016)'nin eğitim kurumlarında gerçekleştirdikleri ve lider-üye etkileşimi düzeyi arttıkça çalışanların iş tatminlerinin arttığını belirledikleri ve Laschinger vd., (2007)'nin yüksek kalitedeki lider-üye etkileşimi kalitesine sahip olan hemşirelerin iş tatminlerinin arttı̆̆ını belirledikleri çalışmalarıyla benzerlik göstermektedir.

Genel olarak daha önceki araştırmalarda konaklama işletmeleri çalışanlarının örgütsel bağlllıkları ve iş tatminleri üzerinde yüksek LÜE kalitesinin pozitif etkisinin bulunduğuna yönelik elde edilen sonuçlar bu çalışmanın bulguları ile de doğrulanmıştır. Bununla birlikte, araştırma değişkenlerini alt boyutları ile ele alan bu araştırmada LÜE'nin sadece profesyonel sayg1 boyutunun örgütsel bağll1ı̆̆ın duygusal ve normatif bağlılık boyutları üzerinde, profesyonel saygı ve bağlılık boyutlarının ise iş tatmini üzerinde etkili olduğu belirlenmiştir. Astların LÜE bağlamında etki, katkı, bağlılık ve profesyonel saygı algılamaları yüksek olduğu halde, örgütsel bağlılığın boyutları ve iş tatmini üzerinde "etki" ve "katkı" boyutunun anlamlı bir etkisi tespit edilememiştir.

Araştırmanın bulguları göstermektedir ki liderlerin mesleki tecrübelerine, bilgilerine, becerilerine dayalı olarak oluşan profesyonel saygı, astların duygusal ve normatif bağlılıklarını etkilemektedir. Bu bağlamda alanında kendisini ispatlamış olan liderler ile çalışan astlar işletmelerini benimsemekte ve işletmelerine karşı kendilerini borçlu hissetmektedirler. Araştırmanın bir diğer sonucu da, astların mesleki anlamda kendisini kanıtlamış liderlerle çalışmalarının ve liderleri ile karşılıklı olarak birbirlerine bağlılık duymalarının astların iş tatminlerinin artmasında etkisinin olduğudur. Böyle bir çalışma ortamında astlar kendilerinin bulunmadığı ortamlarda örgütteki diğer kişilere karşı liderinin kendilerini savunacağını ve her durumda liderlerinin astının yaptığı işlere sahip çıkacağını düşünmektedirler.

\section{Araştırmanın Sınırlılıkları ve Gelecek Çalışmalar İçin Öneriler}

Literatürde LÜE'nin örgütsel bağlllık ve iş tatmini üzerindeki etkisini turizm sektöründe ve özellikle konaklama işletmelerinde birlikte ele alan araştırmaların son derece sınırlı olması nedeniyle, gerçekleştirilen bu çalışma ile literatüre katkıda bulunulmak istenmiştir. Diğer çalışmalar gibi bu çalışmanın da bazı sınırlılıkları bulunmaktadır. Öncelikle sadece Antalya'nın Belek bölgesindeki beş yıldızlı konaklama işletmelerinde yapılmış olmasından dolayı, bu araştırmadan elde edilen sonuçlara dayanarak tüm konaklama işletmeleri çalışanlarına yönelik bir genelleme yapılması söz konusu değildir. Gelecekte farklı kültürlere sahip ve değişik coğrafyalarda yer alan konaklama işletmelerinde benzer çalışmalar yapılabilir. Ayrıca LÜE ile örgütsel güven, örgütsel adalet, takım etkinliği ve nepotizm gibi araştırma değişkenleri birlikte ele alınarak yapılacak çalışmalardan elde edilecek sonuçlarla literatüre katkıda bulunulabilir. Belirtilenlere ilave olarak, lider-üye etkileşiminin tam olarak sınanabilmesi için gelecekte yapılacak çalışmalarda hem astların liderleriyle hem de liderlerin astlarıyla etkileşimlerine ilişkin görüşlerinin alınması önerilmektedir.

\section{KAYNAKÇA}

Akkoç, İ. ve Çiftçi, A. F. (2016). Lider-Üye Etkileşiminin Tükenmişliğe Etkisinde İş Doyumunun Aracılık Rolü: Eğitim Sektöründe Bir Araştırma, Uluslararası İktisadi ve İdari Bilimler Dergisi, 2(2): 193-211. 
Alkış, H. (2008). Frederick Herzberg'in Çift Etmen (Hijyen-Motivasyon) Kuramının İş Görenin İş Tatminine Etkisi ve Otel İşletmelerinde Bir Uygulama, Yayınlanmamış Doktora Tezi, Gazi Üniversitesi, Ankara.

Allen, N. J. and Meyer, J. P. (1990). The Measurement and Antecedents of Affective, Continuance and Normative Commitment to the Organization, Journal of Occupational and Organizational Psychology, 63(1): 1-18.

Antalya İl Kültür ve Turizm Müdürlüğü (2010). Bakanlığımızdan Belgeli Konaklama Tesisleri İstatistikleri.https://antalya.ktb.gov.tr/TR-175713/bakanligimizdan-belgeli-konaklama-tesisiistatistikleri.html (Erişim Tarihi: 15.05.2018).

Arslantaş, C. C. (2007). Lider-Üye Etkileşiminin Yöneticiye Duyulan Güven Üzerindeki Etkisini Belirlemeye Yönelik Görgül Bir Çalışma, Tisk Akademi, 2(3):160-173.

Avcı, N.ve Küçükusta, D. (2009). Konaklama İşletmelerinde Örgütsel Öğrenme, Örgütsel Bağlılık ve İşten Ayrılma Eğilimi Arasındaki İlişki, Anatolia: Turizm Araştırmaları Dergisi, 20(1): 33-44.

Avcı, U. ve Turunç, Ö. (2012). Dönüşümcü Liderlik ve Örgüte Güvenin Kariyer Memnuniyetine Etkisi: Lider-Üye Etkileşiminin Aracılık Rolü, Journal of Alanya Faculty of Business/Alanya Isşletme Fakültesi Dergisi, 4(2): 45-55.

Balay, R. (2000). Özel ve Resmi Liselerde Yönetici ve Öğretmenlerin Örgütsel Bağlllığı (Ankara İl Örneği), Yayınlanmamış Doktora Tezi, Ankara Üniversitesi, Ankara.

Balay, R. (2014). Yönetici ve Öğretmenlerde Örgütsel Bağlllık. (2.Baskl), Ankara: Pegem Akademi.

Baş, T. (2006). Anket Nasıl Hazırlanır, Uygulanır, Değerlendirilir?. (4.Baskı), Ankara: Seçkin Yayınları.

Baş, T., Keskin, N. ve Mert, İ. S. (2010). Lider Üye Etkileşimi (Lüe) Modeli ve Ölçme Aracının Türkçe'de Geçerlik ve Güvenilirlik Analizi - Leader Member Exchange (Lmx) Model and Validity and Reliability of Its Instrument in Turkish, Ege Akademik Bakış, 10(3): 1013-1039.

Bolat, İ. (2011a). Lider Üye Etkileşimi ve Tükenmişlik İlişkisi, İş-Güç Endüstri İlişkileri ve İnsan Kaynaklarl Dergisi, 13(2): 63-80.

Bolat, O. İ. (2011b). Öz Yeterlilik ve Tükenmişlik İlişkisi: Lider-Üye Etkileşiminin Aracılık Etkisi, Ege Akademik Bakış, 11(2): 255-266.

Bolat, O. İ. ve Bolat, T. (2008). Otel İşletmelerinde Örgütsel Bağlllık ve Örgütsel Vatandaşlık Davranışı İlişkisi, Balıkesir Üniversitesi Sosyal Bilimler Enstitüsü Dergisi, 11(19): 75-94.

Bozkurt, Ö. ve Bozkurt, İ. (2008). İş Tatminini Etkileyen İşletme İçi Faktörlerin Eğitim Sektörü Açısından Değerlendirilmesine Yönelik Bir Alan Araştırması, Doğuş Üniversitesi Dergisi, 9(1): 118.

Brayfield, A. H. and Rothe, H. F. (1951). An Index of Job Satisfaction, Journal of Applied Psychology, 35(5): 307-311.

Buchanan, B. (1974). Building Organizational Commitment: The Socialization of Managers in Work Organizations, Administrative Science Quarterly, 19(4): 533-546.

Casimir, G., Ngee Keith Ng, Y., Yuan Wang, K. and Ooi, G. (2014). The Relationships Amongst Leader-Member Exchange, Perceived Organizational Support, Affective Commitment, and inRole Performance: A Social-Exchange Perspective, Leadership \& Organization Development Journal, 35(5): 366-385. 
Cevrioğlu, E. (2007). Lider-Üye Etkileşimi ile Bireysel ve Örgütsel Sonuçlar Arasındaki İlişki: Ampirik Bir Inceleme, Yayınlanmamış Doktora Tezi, Afyonkarahisar Kocatepe Üniversitesi, Afyonkarahisar.

Clark, A., Oswald, A. and Warr, P. (1996). Is Job Satisfaction U-Shaped in Age?, Journal of Occupational and Organizational Psychology, 69(1):57-81.

Çalışkan, S. C.(2009). Turizm İşletmelerinde Liderlik Tarzları ve Lider-Üye Etkileşimi Kalitesi (Lüe) Üzerine Bir Çalışma, Trakya Üniversitesi Sosyal Bilimler Dergisi, 11(2): 219-241.

Çekmecelioğlu, H. G. ve Ülker, F. (2014). Lider-Üye Etkileşimi ve Çalışan Tutumları Üzerindeki Etkisi: Eğitim Sektöründe Bir Araştırma, Kocaeli Üniversitesi Sosyal Bilimler Dergisi, 28: 35-58.

Çöp, S. ve Öztürk, Y. (2017). Lider-Üye Etkileşiminin Örgütsel Sessizlik Üzerindeki Etkisi: Konaklama İşletmelerinde Bir Araştırma, İşletme Araştırmaları Dergisi, 9(2): 37-68.

Dansereau Jr. F., Graen, G. and Haga, W. J. (1975). A Vertical Dyad Linkage Approach to Leadership Within Formal Organizations: A Longitudinal Investigation of the Role Making Process, Organizational Behavior and Human Performance, 13: 46-78.

Dienesch, R. M. and Liden, R. C. (1986). Leader-Member Exchange Model of Leadership: A Critique and Further Development, Academy of Management Review, 11(3): 618-634.

Erol, G. (2012). Liderlik Tarzları ve Örgütsel Sessizlik İlişkisi: Otel İşletmelerinde Bir Araştırma, Yayınlanmamış Yüksek Lisans Tezi, Balıkesir Üniversitesi, Balıkesir.

Eşitti, B. (2017). Konaklama İşletmelerinde Dışlanma, İş Gerilimi, Bağlllık İhtiyacı ve İş Performansı İlişkisi: Lider Üye Etkileşiminin Aracı Rolü, İş ve İnsan Dergisi, 5(1): 47-59.

Garg, S. and Dhar, R. L. (2014). Effects of Stress, LMX and Perceived Organizational Support on Service Quality: Mediating Effects of Organizational Commitment, Journal of Hospitality and Tourism Management, 21: 64-75.

Göksel, A. ve Aydıntan, B. (2012). Lider-Üye Etkileşimi Düzeyinin Örgütsel Bağlllık Üzerine Etkisi: Görgül Bir Araştırma, Süleyman Demirel Üniversitesi İktisadi ve İdari Bilimler Fakültesi Dergisi, 17(2):247-271.

Graen, G. B. and Uhl-Bien, M. (1995). Relationship-Based Approach to Leadership: Development of Leader-Member Exchange (LMX) Theory of Leadership Over 25 Years: Applying a Multi-Level Multi-Domain Perspective, The Leadership Quarterly, 6(2): 219-247.

Gül, H. (2002). Örgütsel Bağlılık Yaklaşımlarının Mukayesesi ve Değerlendirmesi, Ege Akademik Bakış Dergisi, 2(1): 37-56.

Hair, Jr. J. F., Black, W. C., Babin, B. J. and Anderson, R.E. (2014). Multivariate Data Analysis. (7rded.), USA: Pearson Education Limited.

İşcan, Ö. F. ve Sayın, U. (2010). Örgütsel Adalet, İş Tatmini ve Örgütsel Güven Arasındaki İlişki, Atatürk Üniversitesi İktisadi ve İdari Bilimler Dergisi, 24(4): 195-216.

Janssen, O. and Van Yperen, N. W. (2004). Employees' Goal Orientations, The Quality of LeaderMember Exchange, and The Outcomes of Job Performance and Job Satisfaction, Academy of Management Journal, 47(3): 368-384.

Javaheri, H., Safarnia, H. and Mollahosseini, A. (2013). The Impact of Cultural Intelligence (CQ) on Leader-Member Exchange (LMX). Interdisciplinary Journal of Contemporary Research in Business, 4(9): 538-546. 
Joo, B. K. (2010). Organizational Commitment for Knowledge Workers: The Roles of Perceived Organizational Learning Culture, Leader-Member Exchange Quality, and Turnover Intention, Human Resource Development Quarterly, 21(1): 69-85.

Kanter, R. M. (1968). Commitment and Social Organization: A Study of Commitment Mechanisms in Utopian Communities, American Sociological Review, 33(4): 499-517.

Kaşlı, M. ve Aytemiz, S. O. (2010). Kişilik Özellikleri, Lider-Üye Etkileşimi ve Tükenmişlik İlişkisi, Kütahya Dumlupinar Üniversitesi Sosyal Bilimler Dergisi, 27: 109-122.

Kim, P. B., Poulston, J. and Sankaran, A. C. (2017). An Examination of Leader-Member Exchange (LMX) Agreement Between Employees and Their Supervisors and Its Influence on Work Outcomes, Journal of Hospitality Marketing \& Management, 26(3): 238-258.

Kim, S., O'Neill, J. W. and Cho, H. M. (2010). When Does an Employee Not Help Coworkers? The Effect of Leader-Member Exchange on Employee Envy and Organizational Citizenship Behavior, International Journal of Hospitality Management, 29(3): 530-537.

Kinicki, A. J. and Vecchio, R. P. (1994). Influences on The Quality of Supervisor-Subordinate Relations: The Role of Time-Pressure, Organizational Commitment, and Locus of Control, Journal of Organizational Behavior, 15(1): 75-82.

Kültür ve Turizm Bakanlığı (2018). Turizm İşletmesi Belgeli Tesisler. https://yigm.ktb.gov.tr/TR9579/turizm-tesisleri.html (Erişim tarihi:15.05.2018).

Laschinger, H. K. S., Purdy, N. and Almost, J. (2007). The Impact of Leader-Member Exchange Quality, Empowerment, and Core Self-Evaluation on Nurse Manager's Job Satisfaction, Journal of Nursing Administration, 37(5): 221-229.

Li, X., Sanders, K. and Frenkel, S. (2012). How Leader-Member Exchange, Work Engagement and HRM Consistency Explain Chinese Luxury Hotel Employees' Job Performance. International Journal of Hospitality Management, 31(4): 1059-1066.

Liden, R. C. and Graen, G. (1980). Generalizability of the Vertical Dyad Linkage Model of Leadership, Academy of Management Journal, 23(3): 451-465.

Liden, R. C. and Maslyn, J. M. (1998). Multidimensionality of Leader-Member Exchange: An Empirical Assessment Through Scale Development, Journal of Management, 24(1): 43-72.

Meyer, J. P. and Allen, N. J. (1991). A Three-Component Conceptualization of Organizational Commitment. Human Resource Management Review, 1(1): 61-89.

Meyer, J. P., Allen, N. J. and Smith, C. A. (1993). Commitment to Organizations and Occupations: Extension and Test of a Three-Component Conceptualization. Journal of Applied Psychology, 78(4): $538-531$.

Meyer, J. P., Irving, P. G. and Allen, N. J. (1998). Examination of the Combined Effects of Work Values and Early Work Experiences on Organizational Commitment, Journal of Organizational Behavior, 19(1): 29-52.

Mowday, R. T., Steers, R. M. and Porter, L. W. (1979). The Measurement of Organizational Commitment, Journal of Vocational Behavior, 14(2): 224-247.

Oshagbemi, T. (2000). Gender Differences in the Job Satisfaction of University Teachers, Women in Management Review, 15(7): 331-343. 
Sığrı, Ü. (2007). İş Görenlerin Örgütsel Bağlllıklarının Meyer ve Allen Tipolojisiyle Analizi: Kamu ve Özel Sektörde Karşılaştırmalı Bir Araştırma, Anadolu Üniversitesi Sosyal Bilimler Dergisi, 7(2): 261-278.

Şahin, F. (2011). Lider-Üye Etkileşimi İle İşten Ayrılma Niyeti Arasındaki İlişki Üzerinde Cinsiyetin Etkisi, Ege Akademik Bakış, 11(2): 277-288.

Tanrıverdi, H. ve Kahraman, O. C. (2016). 5 Yıldızlı Otel İşletmelerinde Lider-Üye Etkileşimi ve İşe Yabancılaşma İlişkisi: Marmaris ve İstanbul Destinasyonlarında Bir Araştırma, Dokuz Eylül Üniversitesi Sosyal Bilimler Enstitüsü Dergisi, 18(3): 463-493.

Toker, B. (2006). Konaklama İşletmelerinde İş Gören Motivasyonu ve Motivasyonun İs Doyumuna Etkileri: İzmir'deki Beş ve Dört Yıldızlı Otellere Yönelik Bir Uygulama, Yayınlanmamış Doktora Tezi, Dokuz Eylül Üniversitesi, İzmir.

Toker, B. (2007). Demografik Değişkenlerin İş Tatminine Etkileri: İzmir'deki Beş ve Dört Yıldızlı Otellere Yönelik Bir Uygulama, Doğuş Üniversitesi Dergisi, 8(1): 92-107.

Turgut, H., Tokmak, I., ve Ates, M. F. (2015). Lider-Üye Etkileşiminin İşgören Performansına Etkisinde Çalışanların Örgütsel Adalet Algılarının Rolü, Çankırı Karatekin Üniversitesi İktisadi ve İdari Bilimler Fakültesi Dergisi, 5(2): 1-26.

Turunç, Ö. ve Avcl, U. (2015). Algılanan Örgütsel Destek ve Lider-Üye Etkileşiminin İşten Ayrılma Niyeti Üzerindeki Etkisi: İş Stresinin Aracılık Rolü, Seyahat ve Otel İşletmeciliği Dergisi, 12 (1): 43-63.

Türkiye Otelciler Federasyonu [TÜROFED]. (Ekim 2010). Turizm Raporu. Yıl:1, Sayı: 2, İstanbul.

Uçar, Z. (2019). Lider Üye Etkileşimi Lensinden Paternalist Liderlik ve İş Tatmini İlişkisi, Bitlis Eren Üniversitesi İktisadi ve İdari Bilimler Fakültesi Akademik İzdüşüm Dergisi, 4(1): 28-49.

Ugboro, I. O. and Obeng, K. (2000). Top Management Leadership, Employee Empowerment, Job Satisfaction, and Customer Satisfaction in TQM Organizations: An Empirical Study, Journal of Quality Management, 5(2): 247-272.

Wang, C. J. (2016). Does Leader-Member Exchange Enhance Performance in the Hospitality Industry? The Mediating Roles of Task Motivation and Creativity, International Journal of Contemporary Hospitality Management, 28(5): 969-987.

Wiener, Y. (1982). Commitment in Organizations: A Normative View, Academy of Management Review, 7(3): 418-428.

Yalçın, A. ve İplik, F.N. (2005). Beş Yıldızlı Otellerde Çalışanların Demografik Özellikleri İle Örgütsel Bağlılıkları Arasındaki İlişkiyi Belirlemeye Yönelik Bir Araştırma: Adana İli Örneği, Çukurova Üniversitesi Sosyal Bilimler Enstitüsü Dergisi, 14 (1): 395-412.

Yoon, J. and Thye, S. R. (2002). A Dual Process Model of Organizational Commitment: Job Satisfaction and Organizational Support, Work and Occupations, 29(1): 97-124. 